\title{
INVENTING URBANITY: URBAN MOVEMENTS IN POLAND
}

\author{
PAWEŁ KUBICKI ${ }^{1}$ \\ ${ }^{1}$ Jagiellonian University, Institute of European Studies, ul. Ingardena 3, 30-060 Kraków, Poland. \\ ORCID: 0000-0001-9493-8283, Email: pawel.kubicki@uj.edu.pl
}

\begin{abstract}
The article discusses the process of formation and transformation of urban movements in Poland. Conclusions are based on the data collected during the research project "Urban Social Movements in Poland" supported by the National Science Centre. For the requirements of the project was adopted a method of qualitative research using the techniques of in-depth narrative interviews, participant observations and secondary data analysis. The author conducted 30 in-depth interviews with leaders of urban movements from sixteen cities. The article describes the process of structuralization and the creation of identity of the Polish urban movement and their role on the local political stage, stressing, in particular, their significant role as a creators of a new discourse in Polish cities.
\end{abstract}

KEYWORDS: urban movements, Poland, city, urbanity, urban polices, discourse

\section{INTRODUCTION AND METHODOLOGY}

The article consists of five sections and a summary. In the first part the author describes research objectives and methodology. The second part is dedicated to the analysis of the initial phase of development of Polish urban movements after the accession of Poland to the E.U. In the next, the author describes the process of structuralization and the creation of identity of the Polish urban movement. The fourth section describes the process of mobilization of urban movements in Poland. In the last part, the author discusses the role of Polish urban movements on the local political stage, stressing, in particular, their significant role as a creators of a new discourse in Polish 
cities. Finally, in summary, the author describes some problems which Polish urban movements will have to face in a new context.

The article discusses the process of the rise and development of urban movements in Poland. The conclusions presented in the article are based on the results of a research grant Miniatura 1 017/01/X/HS6/01204 "Miejskie ruchy społeczne w Polsce" (Urban Social Movements in Poland) was supported by the Polish National Science Center ${ }^{1}$. Field research was conducted in 2017-2018 in sixteen Polish cities: Białystok, Bytom, Gdańsk, Gdynia, Gorzów Wielkopolski, Lublin, Łódź, Katowice, Kraków, Mielec, Poznań, Sopot, Toruń, Wrocław, Warszawa, Zielona Góra. The choice of these cities was determined by two main factors. Firstly, in these cities urban movements have the longest and the richest tradition, which allows the analysis of them during a long term perspective, and treating them not only as spontaneous grassroots mobilization but as structured social movements. Secondly, choice of different sized cities, fulfilling different functions, gives a wider perspective and allows the perception of specific features of Polish urban movements.

The fieldwork was collected over 30 in-depth interviews with leaders of particular organizations. An important addition to the empirical material, which is based on indepth interviews, was also participant observation focusing on processes of formation of urban movements in Poland during the last decade. The choice of qualitative methods, (in-depth interviews and participant observation), results from the very nature of the research problem. An important advantage of in-depth interviews is the possibility of a holistic approach, which stems from the fact that the research is carried out in its "natural environment". Unlike surveys, in-depth interviews are less structured and thus they enable the customization of the specific content to the particular context of the study, in the case of this study, the possibility of modification of a particular content while keeping the general scheme of the interview, enables researchers to grasp the specificity of different cities. The in-depth interview included questions related to the following issues: (1) the origin of particular urban social movements, (2) their structure and goals, (3) common frame and self-identification, (4) evaluation of local urban policies and the role of local urban movements in (re)creating such policies, (5) evaluation of local public debate on urban issues and the role of mass-media in such debates (6) the future of urban social movements in particular cities as well as at the national level. However, it should be stressed that a qualitative method have some limitations. The information collected during in-depth interviews are often marked by the respondents' biographical experiences, including their worldview, available knowledge and ability to process it. Therefore, in my study I am using various research techniques: participant observation as well as analysis of secondary data documents, it is possible to examine interviews critically. By applying various research techniques, I was able to triangulate the results as a control of the research material.

\section{URBAN MOVEMENTS: A THEORETICAL FRAMEWORK}

Urban movements have become an important power in contemporary cities. The

\footnotetext{
${ }^{1}$ A detailed analysis of the results of this project was conducted in Kubicki (2019).
} 
growing importance of urban movements has resulted in increased interest both in various academic disciplines as well as in journalism, which has resulted in a significant number of publications on this topic. Paradoxically, such interest has contributed to blurring this term, so that many different activities in the city space are defined in terms of "urban movements". In fact, the city space has always been a scene for collective behavior and mobilization of social movements. From ancient times to the present day we can identify a long list of protests, rebellions, revolutions etc., which took place in cities, but they have not been defined as urban movements. This was because the term "urban movement" was introduced into sociological language relatively recently, just at the beginning of 1970s. The first time this term was used was by Manuel Castells in his "The Urban Question" $(1977)^{2}$ and was developed this concept in his other book “The City and the Grassroots” (1983). For him, urban social movements developed around three major themes: (1) demands focused on collective consumption, (2) defense of cultural identity associated with and organized around a specific territory (3) political mobilization in relationship to the state, particularly emphasizing the role of local government (Castells 1983). Even when the term "urban social movements" ${ }^{3}$ was introduced to academic language, it didn't mean that the matter of urban movements become more clearer. From that time, in response to the consequences of the urban crises, globalization and ascendant neoliberal polices, a new wave of urban activism has been emerging. A lot of analysis of such activisms have stressed the different structural aspects, features and goals. Therefore, in sociological literature on urban movements we can find various definitions of urban movements stressing various aspects and features. It has happened for at least three reasons. Firstly, because of the fact that, as pointed out by Anna Domaradzka; "urban mobilization takes many forms, including traditional civil society organization (grassroots neighborhood organization, housing association, local interest groups), as well as protest initiatives (against profit-oriented urban polices or commercialization of public resources) or political movements for environmental and social justice” (Domaradzka 2018: 607). Secondly, as a consequence of every changing of social, cultural, economic and political conditions, therefore, as described it Magit Mayer, every decade, since 1970s, the specificity, structure and goals of urban social movements have been changing. (Mayer 2011). Thirdly, and probably the most important in this context, is the fact, that theory of urban movements developed in relative isolation from social movement theorizing generally. Despite some positive aspects of this, Chris Pickvance identified three negative results of such isolation. Firstly, it meant being cut off from general social movement theory. This was highly significant, since from the 1970s this theorizing was undergoing an explosive growth. Secondly, isolation led to some empirical lacunae. For example, the process of mobilization was neglected in early writing on urban movements. Thirdly, a separation was established between studies of voluntary associations and their interaction with authorities, and studies of urban movements. The final point about the "separate development" of writing on urban movements was

\footnotetext{
${ }^{2}$ Original publication in French, 1972.

${ }^{3}$ In the article I use the abbreviated form "urban movements".
} 
that it was partly influenced by the rise of interest in "new social movements". More usually urban movements have been categorized as an old social movement like the labour movement, because of the allegedly material character of their demands. To study them was therefore to study a residue of diminishing interest. This view contributed to the lack of interest in urban movements among writers on social movements generally (Pickvance 2003: 104-106).

These arguments indicate that in order to analyze urban movements we should create an operational model which takes into account the complexity of the context in which they develop and act. Therefore, I have based my research, on urban movements in Poland, on three main assumptions. Firstly, I understand urban movements according to the definition of Hans Pruijt, who defined them as: "Urban movements are social movements through which citizens attempt to achieve some control over their urban environment. The urban environment comprises the built environment, the social fabric of the city, and the local political process" (Pruijt 2007: 1). Secondly, the structure, goals and strategy of Polish urban movements were formed by the specificity of the transformation of Polish structure at the beginning of the $21^{\text {st }}$ century, driven by accession to the EU (2004) and coming to power a new generation (new bourgeoisies) at the beginning of 21st century. Thirdly, they are a part of the new social movements according to Claus Offe definition (Offe 1985) and their activity and frame of reference are determined by: (1) Spatial turn (Foucault 1986; Soja 1996), determining the intellectual discourse of the contemporary urban question. (2) A significant shift in the subjectivity of the city as a frame of reference which determined collective identity and behavior (Glaeser 2012, Barber 2013). (3) Consequence of neoliberal polices and urban crises (Mayer 2011, Harvey 2012, Florida 2017).

\section{THE ORIGIN: INVENTING URBANITY}

Polish urban movements, for many reasons, have been developing much later then their Western counterparts. According to my respondents, the origin of Polish urban movements is dated around 2007-2008 ${ }^{4}$. This date also indicates the beginning of new waves of Western urban movements which have been mobilized as a reaction to the financial crises of 2007-2008. In the Polish case however, urban activism has different roots. This is a consequence of the specifically Polish urban question. In order to clarify this situation, it is necessary to shed some light on the specifically Polish context. ${ }^{5}$

The process of formation of a Polish national identity within an ethnic model in which Polishness was almost exclusively described from the perspective of noble culture and peasant folklore, and the idea of the city was presented in terms of foreign values threatening the homogeneous ethnic culture. The notion of the city and urbanity as a foreign, outside national entity is one of the most durable stereotypes functioning in Polish culture. While over past centuries Western Europe was experiencing a period of dynamic development of cities and urbanity, in Poland, however a whole

\footnotetext{
${ }^{4}$ Some grassroots organizations which had transformed into urban social movement set up a few years earlier.

${ }^{5}$ A detailed analysis of this process was conducted in Kubicki (2016a).
} 
set of unfavorable circumstances, along with the ongoing historical processes, caused Poland to experience this process only marginally. With the lack of its own sovereign state throughout the whole 19th century, enormous damage in the physical tissue and socio-cultural aspect taken during the Second World War, the anti-bourgeoisie politics of the Polish Republic of People and process of ruralisation of cities - all of these factors had an influence on the exclusion of urbanity from the national public discourse. At the end of 1980s Polish sociologist Jan Turowski described the Polish urban question as: "a country of accelerated industrialisation and delayed urbanisation" (Turowski 1988: 200-201). Moreover, Polish cities were among the most culturally diverse cities in Europe up until World War II, inhabited by people of different nationalities and religions. As a consequence of World War II (the Holocaust, displacements etc.) the multiculturalism of Polish cities was completely destroyed. Additionally, the multicultural heritage of cities, especially those with German and Jewish heritage, was perceived as foreign and dangerous to Polish monocultural identity, and thus eradicated from national public discourse after World War II. As a result of the factors described above, the new inhabitants (post-war migrants) of cities for a long time sought legitimation for their social and cultural identities mostly in the idea of the nation and family ties, rather than in the cities where they lived. Consequently, in Polish society, but especially in the cities, there has accrued a so-called sociological vacuum. (Nowak 1979). In such a vacuum, the only levels of identification were 'family' in a narrow sense and the 'nation', understood as an imagined symbolic community; the 'city', meanwhile, remained an alien, or at best an indifferent space. Therefore, just at the beginning of the $21^{\text {st }}$ century, the Polish urban question was described by Ewa Rewers in this way: "in this respect, Polish cities are deficient, their urban character is unrecognised, and the consciousness of the city overlooked" (Rewers 2010: 14). All these factors strongly influence the specific character of Polish urban movements which, at the beginning of their process of formation, put attention on different issues than their Western counterparts. Polish urban movements predominated by well-educated urban middle class were focused mostly on cultural issues, such as: identity and heritage of the city, esthetic of the city, spatial planning. Therefore, the first stage of their formation could be described as a process of "inventing urbanity" (Kubicki 2016a) rather than in terms of an idea of "the right to the city" a common frame of global urban movements.

Polish urban movements have been developing in an evolutionary way. There was no one single milestone which could initiate mass mobilization, as in case of many social movements. There were rather a set of structural changes and opportunities since the beginning of new millennium. Therefore, it is difficult to indicate concrete dates of the first stage of formation Polish urban movements, but for the purposes of this research project I suggest that it was 2007-2014.

One of the most significant outcomes of research data was the fact that in each city, activists are firmly convinced that they are a pioneers of urban activism in their cities. A typical answer to the question about the legacy of urban activism in a particular city was like this: No, we're self-taught in this field. (...). We learned from each other, from our own experiences. (RM11). We, as activists, had to invent everything, all the procedures, all 
the know-how (RM10). To be honest, I don't remember there being any organization that would be treated the city and urbanity in such a holistic way. (RM22). In fact, in Polish cities in 1980s and 1990s acted social movements which could be defined as proto-urban social movements. These organizations were especially connected with anarchist movements (Żuk 2001, Pomieciński 2016, Pluciński 2016) and environmental movements (Gliński 1996). Some sociologist stressed that in these processes we should seek the genesis of contemporary Polish urban movements (Nowak 2015, Pluciński 2015, Wróbel 2011.) In practice institutional memory of such activism has been completely erased. Contemporary activists are absolutely convinced that they have nothing in common with social movements form 1980s and 1990s. For example Kraków is the city where in 1980s and 1990s the environmental movements had the strongest tradition (Gliński 1996: 296). But contemporary activists who are focusing on the main problem of this city's - air pollution, when being asked if they draw on experiences, knowledge from of such previous movements, answered: No. I don't think so, because we didn't have anything to draw from either. (...). KAS (Krakow Smog Alert) was the first organization to take up the subject (air pollution). (RM06).

This belief, that urban activity in Poland has a pioneering character is also consequence of the fact, that local grassroots activities for long time were just "invisible". It was because they did not fit into an intellectual framework describing civic activity in the Polish pattern of culture which was predominated by "grand narratives". Moreover, Polish urban middle class were widely described as a beneficiary of the transformation and, in fact, for long time they also self-identified themselves in this way. Therefore, they were not interested in social mobilization, protesting, developing social movements, and it was a time of "social non-movement" (Nowak 2006: 110). The consequence of this situation was that: "the appearance of urban social movements on the stage of civic activism surprised sociologists in Poland". (Pluciński 2015: 412-413). Polish urban movements have appeared as a new phenomenon both for sociologists and journalists who wish to describe them, as well as for their own activists themselves: We, as activists, had to invent everything, all the procedures, all the know-how (RM10). Therefore, respondents asked about a sense of common identity of Polish urban movements answered, that it is: a generational experience (RM11). In sociology the term of generation is defined as: "a group of people who have experienced the same important historical events, who have experienced the same situations, who have reacted to the same situations" (Sztompka 2005: 154). In the case of Polish urban movements "the same experiences" which have linked people and organizations together, could be describe as the process of "inviting urbanity". A cited respondent's sentence depicted this process: And so it began in Gdańsk, we slowly began to discover the tools of participation and set up such a group of people from the cultural circles and architects, and we did such activities as were also done in other cities at that time, such as walks, historical-architectural walks, or reading the city through literature, through art, well, there was a lot of it in our country, which really fuelled such a trend for urban activism. (RM01) Each generation requires new narrations to legitimize new identities. In this particular case, the Polish urban movements, inventing urbanity and using it to legitimize their new identities. The crucial role in this process was fulfilled by a 
new social category in Polish cities, the so called "new bourgeoisies". The rise of the new bourgeoisies has been observed since the very beginning of $21^{\text {st }}$ century. This social category is defined as 30-40 years old, children and grandchildren of peasant migrants who have grown up in cities and have started building their identity in relation to urbanity and the urban culture. Research on the new bourgeoisies indicates that they are crucial to the process of redefining the role of urbanity and the urban culture in Poland (Kubicki 2011, Galent and Kubicki 2010). Moreover, a new urban economy, based on production of symbols and knowledge, makes the urban cultures attractive for them and are loaded with more positive values. Also, the process of integration within the EU created new opportunities for urban activities. One of the key principles of the EU - free movements of goods, services, capital and labour, stimulates diffusion of urban patterns of culture, good practices etc. This aspect was often stressed by respondents during interviews, when they were asked: 'why have you decided to engage in urban movements?', they often answered: first of all, the ERASMUS programme, because thanks to that we could travel around and see how other cities look, you could see how the public space looks (RM16). I had the opportunity to travel a lot in European cities, I saw a better world and I asked myself why could this not be in ours cities. (RM20). The process of inventing urbanity has opened new opportunities for the new bourgeoisies. Engagement in urban activity was also correlated with the sense of self-fulfilment, while other ways of self-realization were already blocked by older generations: Warsaw in 2007 was in a specific period, it was a "white town" and it was intertwined with discussions about public space and I, at that time 23 years old, could join to this and become a leader. It was enough to take up the topic half a year earlier to frame the rules of the game. (RM16). The generational dimension of Polish urban movements determined that they are predominated by people of the similar age of 30-40 years: Statistics of our Facebook fanpage show that the average age of people who are engaged are 30-35 years old. (RM06), Mainly it is people about 35 years old (RM13). Also other researchers indicated that grassroots local activism in Poland are predominated by this cohort. Marek Nowak investigated volunteer organizations in Poland, and stressed that they consist of the similar cohort, namely 31-49 years old (Nowak 2015: 286). However, Dominika Polańska analyzed activists in informal initiatives that were formed in various Polish cities and focus on some specific urban issues in their activity, indicated that the average age of activists was 33 years (Polańska 2018: 3-4).

In the time when urban movements have been forming in Poland's cities, there have taken place some very important processes: during the years 2007-2011, eleven Polish cities were involved in the competition for the title of the European Capital of Culture 2016. This competition brought crucial changes in many spheres of city life, played an important role in the process of shaping local identities and strengthened social capital and could be described as the "European Capital of Culture effect." ${ }^{\circ}$ The most important consequence of the "ECOC effect" has been the fact that the competition triggered intensive public discussions about urbanity and urban culture in Poland.

\footnotetext{
${ }^{6}$ A detailed analysis of ECOC effect was presented in the book: Kubicki, Paweł. and Bożena, Gierat-Bieroń and Joanna Orzechowska Wacławska. 2020, The European Capital of Culture 2016 effect: how the ECOC competition changed Polish cities, Berlin: Peter Lang.
} 
Therefore, for many activists the "ECOC effect" was perceived as the milestone in the process of inventing urbanity: It could be said that such a stirring of social movements, which was triggered thanks to the European Capital of Culture competition, could have a feature of a "levée en masse" of various groups and organizations, especially connected with culture policies in the city. (RM09). It was (ECOC) such a kick that if I have to indicate the date of a new era of Łódź, it was from that moment, for sure. (RM11).

The processes described determined the context in which Polish urban movements have been forming in the first decade of $21^{\text {st }}$ century. Therefore, despite the fact, that urban activism in Poland is diverse (Domaradzka 2017, Domaradzka and Wijkström 2016, Kowalewski 2013, 2016, Kubicki 2013, 2016b, 2017, Pluciński 2015, 2018, Pluciński and Nowak 2017, Polańska 2016, 2018, Piotrowski and Polańska 2016), in the first stage Polish urban movements has been predominated by the new bourgeoisies and their requirements and interests. As Pluciński pointed out, in Poland: "Ideas created by these three visionaries Jane Jacobs, Jan Gehl, Leon Krier were points of reference for many urban movements and initiatives. (Pluciński 2018: 12). But the context is changing and in the same way is transforming the character and goals of Polish urban movements.

\section{EMOTION: SOCIAL MOBILIZATION}

The processes described above have created a specific urban frame of reference. Thanks to this, urban activism found a fertile soil for their development. But it could not have been an engine for development of social movements. As Castells suggests, social movements are based on emotions, their creation does not begin with the creation of a programme or a political strategy. According to him, for social movements the crucial point is spinning off emotion into action (Castells 2012). Anger and frustration are the emotions which most often stimulate mass mobilization and social movements. Also, in the particular case of Polish urban movements, the crucial mechanism which has transformed grassroots activity into urban movements was the rising anger and frustration at neoliberal urban polices. In my opinion a good illustration of such a process is a respondent's answer to the question about motivations involved in urban movements: I've always been interested in the city, in 2003-2008 I was frustrated by neoliberal governments, and in 2009 I decided to get involved, to get beyond the monitor. (RM12). Respondents indicates that the most common reason for involvement in urban activities was the chaos in spatial planning. The "spatial chaos" has become a catalyzer of mass mobilization, at least, for three reasons. First of all, after accession, thanks to EU funds, as well private capital, Polish cities have become a huge "construction site", what was a consequence of their deep infrastructural backwardness. But, this construction boom coincided with a lack of urban policies, the deregulation of spatial planning, and the dominance of neoliberal ideology. Moreover, in the first years of this construction boom there were not a public, civic control of spatial planning in Polish cities, and this sentence could be a good example of the problem: we went (to the City Hall) for the consultation of the local plan with the authorities - announced according to the law - and the officials are completely lost because someone had actually arrived. 
They had to organize for us a room, because people completely did not use such participatory tools even that was introduced in 1997, and that was 2007. (RM01). The overlap between these three factors has led to the spatial chaos: These are the consequences of transformation and accession to the EU, the consequences of this wild capitalism: investments, developers, shopping centres, office buildings and hotels etc., all at the cost of something (RM13). The cost of such "development" of Polish cities was the devastation of green areas, neighborhood identity etc. Respondents indicated that the problems with special planning issues were the main reason for social mobilization and the setting up of local, grassroots organizations which, over time, have transformed into urban movements. Paradoxically, it also influences the specific structure of Polish urban movements which were, in the early stages, dominated by middle-class professionals (architects, urbanist, sociologist etc.) from big cities where the construction boom had the greatest impact on the local environment: There are some dozens of organizations in the Urban Movements Congress, they are mostly associated with the middle class, intelligentsia, with the academic character of big cities. (RM13)

\section{STRUCTURALIZATION AND IDENTITY}

As Pluciński pointed out: "The urban initiatives and movements that started emerging in 2007-2008 in Poland's largest cities were at first isolated and unaware of the larger context. They were, however, quick to develop their own counter discourse, praxis and strategies as well as (re)construct local public spheres while facing the long tradition of non-urbanity, non-participation and the challenges of neoliberal urbanism" (Pluciński 2018: 660). In fact, in the first decade of $21^{\text {st }}$ century in Polish cities there emerged many of the grassroots organizations which had more in common with NIMBY groups or debating clubs than with urban social movements. The situation has changed thanks to the inherent processes of integration. These processes took place on two levels. On the one hand, it was the formalization of the local urban activities, establishing official structures, mostly by setting up legal associations. On the other hand, it was the nationwide networking - establishing cooperation between the urban movements from dozens of cities.

When it comes to formalization on a local level, respondents indicated two main reasons which determined this process. First of all, it was about ensuring greater cohesion and integration, especially in the case of these organizations which decided to stand for local election: I think, and I suspect that most people in the association agree with me, that it is important to have an official association. This is a good example of the history of formalization: it was said from the beginning that it is important (registration of association), but everyone postponed it until later and at the moment of the first crisis in 2014, when three ours city councilman jumped ship, or were expelled - it was no longer important - then we realized that we need a formal procedures for members and therefore it was a quick submission of documents to The National Court Register and registration at the beginning of 2015. (RM18). Moreover, respondents indicated that official structures increased the importance of urban activity especially in the context of their relations with local authorities and the media: Often it (the association) is used as a "windbreak- 
er", because there are just few people hiding behind this association, but officially it is an association and so it gives it a higher status. (RM08). The process of formalization was also a response to the specific nature of Polish urban movements. Everyday practice of these urban movements are not a spontaneous protest or 'happening' but it consists in disputes with local authorities and/or developers on formal and legal grounds, entering into consultations, pursuing litigations, etc. For these reasons they need to have an official structure registered at the National Court Register: I am absolutely sure, that without an official structure, many of the things we have done so far could not have been done. (...) We were involved in two judicial proceedings at the Provincial Administrative Court, also in relations with the City Council, and we can be a participant in administrative proceedings, initiate administrative proceedings when it is necessary (...)they can't get rid of us so easily then, we are able to exercise the law. (RM05). However, the most common model of urban movement structure has a hybrid character. Such a model consists of a small number of "core" - people who are official members of an association and dozens of those who engage themselves occasionally in direct action. Such a model enhances efficiency and creativity, as well gives legitimization in the local community, as a representation of "ordinary people” and not as just only as NGO experts.

The most important aspect of structuralization has been the development to the nationwide level. The crucial role in this process has been the establishment of the Urban Movements Congress. UMC was established as an informal structure in June 2011 in Poznan during the first ${ }^{7}$ meeting of urban movements from all country. UMC has become the milestone for urban activism in Poland for many reasons. Firstly, because, and thanks to UMC, the term "urban movement" was introduced into Polish public discourse ${ }^{8}$, which has allowed Polish urban movements to create their own identity: It seems to me that we have been using this term: "urban movements" since that meeting (UMC), we worked it out there, and we dared to use it there. (RM01). Secondly, during the congress activists worked out the Urban Theses ${ }^{9}$, which become a common frame joining urban movements in Poland. The Urban Theses based on the crucial values of Polish urban movements: (1) Sustainable development in the spirit of the Leipzig Charter on Sustainable European Cities (2007) - long-lasting, protectiveness towards space, nature and other resources, and oriented towards the quality of life. (2) Participatory urban democracy, combining the will of the majority with the protection of human and minority rights. (3). Social solidarity - ensuring equal opportunities, just social relations and the support of the urban community for all those in need of such support ${ }^{10}$. The Urban Theses became both common ideology (so-called "cityview”), as well as a specific code creating esprit de corps of Polish urban movements:

\footnotetext{
${ }^{7}$ In fact, in 2009 in Łódź and Lublin, took place meetings in which were gathered grassroots organizations interested in urban issues, but no one has ever defined their activities in the term of "urban movements."

${ }^{8}$ There is a common conviction, both with researchers as well activists, that the term "urban movement" describing urban grassroots activism in Poland was the first time used in this time.

${ }^{9}$ In Poznań 2001 was the working out of 9 Theses, next, at IV UMC in Gorzów Wielkopolski in 2015 it has been extended to 15 Theses. More about it: https://kongresruchowmiejskich.pl/urban-theses/

${ }^{10} \mathrm{https}$ ://kongresruchowmiejskich.pl/tezy-miejskie-spis (27.06.20).
} 
For us, these Theses are, I would not like to call them the Bible, but they are such a code, if you want to be among us, you have to accept it. (RM15). Thirdly, regular congressional meetings: Poznań (2011), Łódź (2012), Białystok (2013), Gorzów Wielkopolski (2015) cities of Silesian Region (2017) Ostróda and Iława (2019), have become a kind of ritual which integrates activists and builds identity of urban movements. Integration within the UMC also allowed for the creation of a communication and networking structure. UMC, as I mentioned before, was established as an informal structure, but since 2017 it exists as a legal union of associations. Today the union consists of 44 organizations ${ }^{11}$ from all around the country. Respondents evaluating the role of UMC stressed two important features. Firstly, UMC fulfills the role of urban think-tank which produces and shares knowledge and good practices, gets legal and expert support for each organization and stimulates networking: We have an opportunity to networking, exchange ideas, experiences, from the perspective of different cities, access to expert knowledge: architectural, jurisprudential (RM24). Secondly, especially in smaller cities, membership in UMC increases the prestige of urban activism: such awareness that we are associated in such a larger network is very positive for me personally, because I remember those times when we were perceived here as such local activists from a garbage cans or pavements, and now we are not, because we are creating a network of more than 30 urban movements from all country. (RM15).

Such integration within UMC framework has allowed various and often different organizations to create a common identity of Polish urban movements despite their diversity. Such identity could be described according to the Pluciński's definition of Polish urban movements. The author writes that they: "share some characteristics in spite of their diversity: (1) they consider themselves urban, (2) they are locally based and territorially defined, and (3) they mobilize around the three major goals: collective consumption (or public infrastructure), cultural identity and political self-management' (Pluciński 2018: 7).

\section{URBAN MOVEMENTS AT THE POLITICAL STAGE: THE POWER OF DISCOURSE}

The process of developing of urban movements and crystalizing their identity resulted in the situation that they began to play a significant role on the political stage. In 2010, the first Polish urban movements "My Poznaniacy” (We, the Inhabitants of Poznań) stood for election to the city council in Poznan. They received quite a good result over (9\%), but in accordance with the electoral system - the D'Hondt method - they did not get any seats in the city council. The situation significantly changed during the next election in 2014, when urban movements created an electoral coalition of 9 organizations for all the country. In some cities they received very good results, in Gorzów Wielkopolski and Poznan ${ }^{12}$ were elected to the to the position of mayor, and it was widely described in Polish media as a great success of urban movements. In the same year, two other events showed the growing power of urban movements. In Kraków, the

\footnotetext{
${ }^{11}$ State of affairs on the day: 27.06.2020.

${ }^{12}$ In fact, Jacek Jaśkowiak who was elected as the mayor of Poznań was an official candidate of the Civic Platform, but he, as a former member of local urban movement, had their support.
} 
local urban movement “Kraków przeciw Igrzyskom” (Kraków Against Games) led to a local referendum on the Winter Olympics in 2022. Despite an intensive and very expensive advertising campaign made by the authorities, the 2022 Winter Olympics was rejected by a majority $(69,72 \%)$ of the voters, with a high (by Polish standards) turnout (35,96\%). In Warsaw, however, the urban movement "Miasto Jest Nasze” (The City is Ours) published the "Map of Reprivatisation" which showed connections between politicians, businessman, real estate companies, and lawyers who were involved in the chaotic and dubious processes of real estate reprivatisation in Warsaw. The map has had broad publicity and had significant impact on political reality in the capital of Poland.

Thanks to these reasons and the electoral success in 2014, urban movements began to be perceived as an important player on the local political scene. Therefore, in the next election in 2018 they were often presented as a third power on the cities' political stage. However, despite the fact of mass mobilization and their relatively good publicity, the general result of this election was well below expectations. The main reason of this situation was a specific political context which predominated Polish reality during that time. Even though it was a local election, the character was determined by a nationwide political conflict - a deep polarization between two politics blocks: democratic and pro-European "Civic Coalition" versus populist and nationalistic "The United Right." Therefore, a local election was in fact a plebiscite between two dichotomic forces, and there was no space for a third political power. But even in such an adverse context, in many cities urban movements received some seats in city and/or district council.

Polish urban movements have come to power not through the politics institutions, but thanks to the creation of a new discourse, a new narrative. It occurred because of two main reasons. On the one hand, it was a consequence of the specific nature of the new social movements (Offe 1985, Melucci 1980) - with whom Polish urban movements have much in common. The new social movements are dominated by a well-educated middle class having high resources of cultural capital and thanks to this, having supremacy on the discourse level. On the other hand, it was a consequence of the way in which Polish urban movements have been described. In the first part of the article, I discussed - referring to Pickvance - problems with a weakness of theory of urban social movements as a result of isolation theory of urban social from social movement theorizing generally. However, such a theoretical weakness has also positive results for perceiving urban movements in public discourse. For Pickvance, the first of such a positive feature was the focus of urban movement writing on effectiveness. The very definition of urban social movement referred to a level of effect, not to a type of organization. The effects involved could be urban (improvements in public services) or political (changes in power relations). A second was the interest in political power. A third was the concentration on the political context in which urban movements developed. This recognized that urban movements were not spontaneous responses to objective inequalities or deprivations but formed more easily under certain social and political conditions than others (Pickvance 2003: 104-106). Classical theories of social movements put attention on the processes of mobilization and verbalized collective 
activity in the city space: rebels, protests, happenings etc.. Therefore, they are often presented in public discourse as a movement of protest or outrage and not as creators of a new narrations. But, in the time, when the production and control of information is one of the main attributes of power, in analyses of a social movements we should pay attention rather on this aspect, and not only on analyses of the type of organization or collective actions. It is especially important in the particular example of Polish urban movements, because the main effect of their activity, is not an ability for mass mobilization and significant protests in the city space, but efficiency in realization of their demands - thanks to the ability to creating a dominant interpretive discourse. Such discourse according to Alain Tourain: comprises a set of representations and ideas that constitute a mediating authority responsible above all for constructing an image of the whole of an individual's social life and experience, where at the intermediary level - that of ideological discourse - intellectual choices take place and conditions of communication are forged that impose the rules of the game, and afford some and not others the privilege of being listened to. (Touraine 2009). Such a privilege of being listened to (according to urban policies) has becoming the privilege of urban movements: In my opinion, the media and politicians, have begun to speak the language of urban movements, I don't know if it was only before the elections or on a permanent basis. (RM22). Our presence in the media has made us more professional, as partners to politicians and not as cranks. (RM18). Urban activists are recruited mostly from well-educated middle class, professionals: urbanists, academics, artists, journalists: We try to interest the media about our activity, because urban movements from all over Poland are attracting such people...: specialists, journalists, artists, these are people who are very conscious of the media, social media and can create such a message. (RM22). Therefore, they have an over-representative influence on a dominant interpretive discourse and they are, above all else, the generators of new meanings, symbolic systems and values, which are the foundations of socio-cultural changes in Polish cities. The power of Polish urban movements lies not in their numbers of seats in the city council, but in their ability to create a public discourse and impose their narrative on others.

\section{SUMMARY}

Polish urban movements has been developing over the last decade. During this time they have gone through various stages of development, from spontaneous and atomized local grassroots organizations to nationwide social movements with well-defined identity and structure. They have become significant social players in Polish cities, having the ability to create and impose their own narration about the city and urbanity. They have taken also co-responsibility for the development of urban policies, both on political stage as well as at expert level. However, they will have to face some problems which will determined their future development. According to the research data, two main issues have been identified. First of all is a problem of "stealing narration”. During interviews all respondents indicated that local authorities have took over their narration, the language of urban movements. It was because of this, that in Polish cities the period of huge public infrastructural investments has finished. There- 
fore, local authorities, in order to legitimized their power, have been looking for a new narration related to issues about the quality of life and sustainable development than spectacular investments as previously was the case. Paradoxically, success of urban movements - introducing their demands and ideas into the public discourse, has put them in an uncomfortable position. They are losing their most important advantage the language of story of the better city. Today, the same language is spoken by authorities and urban movements will have difficulty in the future to distinguish themselves from them.

Secondly, in the case of almost every organization, respondents stressed that they have a serious problem with the recruitment of new members, especially from the younger generation than the cohort of 30-40 years old. This problem is determined by two factors. On the one hand, this is the consequence of the generation identity of Polish urban movements. Generation identity creates strong social bonds between people who have participated in the generation's events, and who have experienced the same situations. However, it also creates symbolic boundaries which exclude others who have not had such common experiences. On the other hand, the problem of recruitment is also connected to issues of language. The language of Polish urban movements used to be revolutionary a decade ago, nowadays, this is the language of the mainstream. Therefore, it could not mobilize a younger generation who wants "the change". Moreover, over the last few years in Polish cities there has emerged many of the new and more revolutionary political forces which recruit their members or/and supporters mostly from the younger generation. On the left side there are a new left political parties (Razem and Wiosna), and also very popular with the younger generations are women's movements, as well as youth environment movements such as Extinction Rebellion or Global Climate Strike. On the right, however, there are nationalistic and populist movements which are growing in power, as well as backlash movements protesting against progressive policies in cities, especially in the context of sustainable transport polices.

Despite these problems, Polish urban movements still have dynamism, and new organizations are still joining the UMC. However, the new context in which they find themselves will undoubtedly require a new urban agenda for urban movements.

FUNDING: the Polish National Science Center: Miniatura 1 017/01/X/HS6/01204

CONFLICT OF INTEREST: The author declares no conflict of interest.

\section{REFERENCES}

Benjamin, Barber. 2013. If Mayors Ruled the World. Dysfunctional Nations, Rising Cities. New Haven: Yale University Press. 
Castells, Manuel. 2012. Networks of Outrage and Hope. Social Movements in the Internet Age, Polity. Cambridge: Polity.

-------. 1983. The City and the Grassroots: A Cross-cultural Theory of Urban Social Movements. Berkeley and Los Angeles: University of California Press.

. 1977. The Urban Question. A Marxist Approach. London: Edward Arnold.

Domaradzka, Anna. 2018. "Urban Social Movements and the Right to the City: An Introduction to the Special Issue on Urban Mobilization." Voluntas 29: 607-620. https://doi.org/10.1007/s11266-018-0030-y

------------. 2017. "Leveling the Playfield: Urban Movement in the Strategic Action Field of Urban Policy in Poland.” Pp. 106-118 in City Unsilenced: Urban Resistance and Public Space in the Age of Shrinking Democracy, edited by H. Jeffrey and S. Knierbein. London: Routledge.

Domaradzka, Anna and Filip Wijkström. 2016. "Game of the city re-negotiated: the Polish urban re-generation movement as an emerging actor of a strategic action field.” Polish Sociological Review 3/2016: 291-308.

Foucault, Michele. 1986. “Of other spaces.” Diacritics16(1): 22-27.

Florida, Richard. 2017. The New Urban Crisis: How Our Cities are Increasing Inequality, Deepening Segregation, and Failing the Middle Class - and What we Can Do About It. New York: Basic Books.

Galent, Marcin and Paweł Kubicki. 2010. “An Invisible Revolution. How the Urban Way of Life Is Transforming the Identities of Poles.” Pp. 205-248 in: Collective Identity and Democracy. The Impact of EU Enlargement, edited by M. Góra and Z. Mach. Oslo: Arena.

Glaeser, Edward. 2012. Triumph of the City. How Urban Spaces Make Us Human. London: Pan Books.

Gliński, Piotr. 1996. Polscy Zieloni. Ruch społeczny w okresie przemian. Warszawa: Wydawnictwo IFiS PAN.

Harvey, David. 2012. Rebel Cities. From The Right To The City To The Urban Revolution. London-New York: VERSO.

Kongres Ruchów Miejskich. 2020. Retrieved June 27, 2020 (https://kongresruchowmiejskich.pl).

Kowalewski, Maciej. 2016. Protest miejski. Przestrzenie, tożsamości i praktyki niezadowolonych obywateli miasta. Kraków: Zakład Wydawniczy NOMOS.

-------. 2013. „Organizowanie miejskiego aktywizmu w Polsce: Kongres Ruchów Miejskich.” Przestrzeń społeczna 2: 1-26.

Kubicki, Paweł, Bożena Gierat-Bieroń and Joanna Orzechowska Wacławska. 2020. The European Capital of Culture 2016 effect: How the ECOC competition changed Polish cities. Berlin: Peter Lang.

Kubicki, Paweł. 2019. „Ruchy miejskie w Polsce. Dekada doświadczeń.” Studia Socjologiczne 3(234): 5-30. DOI: 10.24425/sts.2019.126150.

---------. 2017. „Od miejskiego aktywizmu do miejskich ruchów społecznych.” Annales Universitatis Maria Curie-Skłodowska Lublin XXXIV Sectio K: 173-186, DOI: $10.17951 / \mathrm{k} .2017 .24 .2 .173$.

-. 2016a. Wynajdywanie miejskości. Polska kwestia miejska z perspektywy 
długiego trwania. Kraków: Zakład Wydawniczy NOMOS. 2016b. „Polskie ruchy miejskie: polityczne czy kulturowe?” Przegląd Socjologiczny 2/2016: 65-79.

2013. „Polskie ruchy miejskie in statu nascendi.” Pp. 25-35 in Partycypacja obywatelska - decyzje bliższe ludziom, edited by A. Maszkowska and K. Sztop-Rutkowska. Białystok: Fundacja Laboratorium Badań i Działań Społecznych „SocLab”.

-------. 2011. „Nowi mieszczanie - nowi aktorzy na miejskiej scenie.” Przegląd Socjologiczny LX (2-3): 203-227.

Mayer, Margit. 2011. “The right to the city in urban social movements.” Pp. 63-85 in Cities for people, not for profits. Critical urban theory and the "right to the city", edited by N. Brenner, P. Marcuse, and M. Mayer. London: Routledge.

Melucci, Alberto. 1980. "The new social movements: A theoretical approach.” Social Science Information 2: 199-226. doi.org/10.1177/053901848001900201

Nowak, Marek. 2006. „Społeczeństwo obywatelski w Polsce. Poprzez „Solidarność” do społecznego bezruchu." Pp. 82-111 in Czy społeczny bezruch? O społeczeństwie obywatelskim i aktywności we współczesnej Polsce, edited by M. Nowak and M. Nowosielski. Poznań: Instytut Zachodni.

2015. Teoria nieracjonalnego działania. Socjologiczne studium na temat wolontariatu i społecznego aktywizmu. Poznań: Wydawnictwo Naukowe UAM.

Nowak, Stefan. 1979. „System wartości społeczeństwa polskiego.” Studia Socjologiczne 4(75): 155-173.

Offe, Claus. 1985. "New Social Movements: Challenging the Boundaries of Institutional Politics." Social Reaserch 52: 817-868.

Piotrowski, Grzegorz and Dominika V Polańska. 2016. "Radical Urban Movements in Poland - the case of squatting." Miscellanea Anthropologica et Sociologica 17(1): 53-69.

Pluciński, Przemysław. 2018. “Forces of Altermodernization: Urban Social Movements and the New Urban Question in Contemporary Poland.” VOLUNTAS: International Journal of Voluntary and Nonprofit Organizations 29: 653-669. DOI: 10.1007/ s11266-018-0007-x.

-------. 2016. „Jaka demokracja miejska? Przypadek Ruchu Społeczeństwa Alternatywnego." Nowa Krytyka. Czasopismo filozoficzne 36: 133-150.

Pluciński, Przemysław. 2015. „Im lepiej, tym gorzej albo widmo kryzysu miejskich ruchów społecznych?” Ruch Prawniczy, Ekonomiczny i Socjologiczny 1: 409-423.

Pluciński, Przemysław and Marek Nowak. 2017. „E pluribus unum? Źródła i specyfika ruchów miejskich we współczesnej Polsce.” Przegląd Socjologiczny 66/3: 115-135. DOI: $10.26485 / \mathrm{PS} / 2017 / 66.3 / 5$.

Polańska, Dominika V. 2016. “Neoliberal Post-Socialist Urban Transformation and the Emergence of Urban Social Movements in Poland.” Pp. 311-334 in Urban Uprisings: Challenging Neoliberal Urbanism in Europe, edited by M. Margrit. London: Palgrave Macmillan.

-. 2018. "Going against institutionalization: New forms of urban activism in Poland.” Journal of Urban Affairs, Published online: 13 Feb 2018: 1-12. 
DOI: $10.1080 / 07352166.2017 .1422982$.

Pomieciński, Adam. 2016. „Radykalne miasta. Ruch anarchistyczny jako ruch miejskiego protest.” Journal of Urban Ethnology 14: 29-41.

Pickvance, Chris. 2003. "From urban social movements to urban movements: a review and introduction to a symposium on urban movements." International Journal of Urban and Regional Research 27: 102-109.

Pruijt, Hans. 2007. “Urban movements.” Pp. 5115-5119 in Blackwell encyclopedia of sociology, edited by $G$. Ritzer. Malden: Blackwell.

Rewers, Ewa. 2010. “Wprowadzenie.” Pp. 5-14 in Miasto w sztuce - sztuka miasta, edited by E. Rewers. Kraków: Universitas.

Soja, Edward. 1996. Thirdspace: Journeys to Los Angeles and other real-and-imagined places. Oxford: Blackwell.

Sztompka, Piotr. 2005. Socjologia. Analiza społeczeństwa. Kraków: Wydawnictwo Znak. Touraine, Alain. 2009, Thinking Differently. Cambridge-Malden MA: Polity Press.

Turowski, Jan. 1988. „Model urbanizacji a problemy rozwoju małych miast.” Studia Socjologiczne 3: 200-201.

Wróbel, Sylwester. 2011. „Teoretyczne problemy miejskich ruchów politycznych.” Pp. 29-57 in Teoretyczne problemy ruchów społecznych i politycznych, edited by S. Wróbel. Toruń: Wydawnictwo Naukowe GRADO.

Żuk, Piotr. 2001. Społeczeństwo w działaniu. Ekolodzy, feministki, skłotersi. Socjologiczna analiza nowych ruchów społecznych w Polsce. Warszawa: Wydawnictwo Naukowe SCHOLAR.

\section{BIOGRAPHICAL NOTE}

Paweł Kubicki is sociologist, professor at the Institut of European Studies Jagiellnian Univesity Kraków, Poland.

OPEN ACCESS: This article is distributed under the terms of the Creative Commons Attribution Non-commercial License (CC BY-NC 4.0) which permits any non-commercial use, and reproduction in any medium, provided the original author(s) and source are credited. 
